\title{
Malignant Peritoneal Germ Cell Tumor
}

National Cancer Institute

\section{Source}

National Cancer Institute. Malignant Peritoneal Germ Cell Tumor. NCI Thesaurus. Code C136410.

A malignant germ cell tumor that affects the peritoneum. 